\title{
IMPLEMENTASI KEBIJAKAN JAMINAN KESEHATAN NASIONAL DI KABUPATEN HALMAHERA UTARA
}

\author{
Richard Djiko ${ }^{1}$, Putra Sian Arimawa ${ }^{2}$, , Charles H.S. Tangkau ${ }^{3}$ \\ 1,2 Politeknik Pedamaian Halmahera \\ ${ }^{3}$ Magister Administrasi Negara, Universitas Negeri Manado \\ Email: ${ }^{1}$ choirulkurniawan58@gmail.com, ${ }^{2}$ sianarimawa@gmail.com, \\ ${ }^{3}$ charles_tangkau09@yahoo.com
}

\begin{abstract}
The Study aim to examine how the implementation of national health insurance policy and what are the obstacles in implementing national health insurance policy through health insurance administering board (BPJS) in North Halmahera Regency. In this study researchers used descriptive qualitative methods. The data used in this research are primary and secondary data. Data collection used interview technique, documentation and observation. In this study the researchers used data analysis techniques from Miles and Huberman that is data reduction, data presentation and conclusion. The results showed that the implementation of national health insurance policy has not run optimally so there are still many people have not participated as participants of national health insurance. In implementing the policy there are some things that become obstacles such as the Implementor not yet understand well what is the standard operational procedures in service to society. Another problem arising from this policy is the status-level reference service system. Another obstacle encountered by researchers in the field is the lack of human resources and supporting tools, there are still many people who complain about the amount of contributions that must be paid by the community.
\end{abstract}

Keyword: Implementation Policy, National Health Insurance.

\section{PENDAHULUAN}

Penyelenggaraan Jaminan Kesehatan bagi Masyarakat di Indonesia telah dimulai semenjak beberapa tahun yang lalu. Dimulai dengan Askeskin (2005-2007) yang merupakan program asuransi kesehatan khusus diperuntukan bagi masyarakat miskin dan tidak mampu dalam memperoleh pelayanan kesehatan. Kemudian pada tahun 2008 berubah menjadi program Jamkesmas dan kemudian pada tahun 2014 berubah menjadi program Jaminan Kesehatan nasional (Mariam, 2016).

Kebijakan Jaminan Kesehatan Nasional di Indonesia dimulai sejak 1 Januari tahun 2014 yang dilakukan secara bertahap dengan harapkan dapat mencapai Universal Health Coveragepada tahun 2019 sebagaimana diamanatkan Undang Undang (Iva, 2014).

Kesehatan merupakan suatu hak dasar yang harus dimiliki oleh setiap manusia, hal ini di amanatkan dalam undang-undang dasar 1945 pasal 28 dan pasal 34, kemudian di dalam Undang-Undang Nomor 23 Tahun 1992 yang kemudian diganti dengan UndangUndang Nomor 36 Tahun 2009 tentang kesehatan yang menegaskan bahwa setiap orang mempunyai hak yang sama dalam memperoleh akses atas sumber daya dibidang kesehatan dan memperoleh pelayanan kesehatan yang aman, bermutu dan terjangkau (Mariam, 2016). Amanat undang- 
undang diatas sangat jelas bahwa setiap orang/warga Negara berhak memperoleh pelayanan kesehatan yang aman, bermutu dan terjangkau.

Untuk memenuhi kebutuhan akan pelayanan kesehatan pemerintah memberikan kepercayaan penuh kepada Badan Penyelenggara Jaminan sosial yang telah diatur dalam Undang-Undang nomor 24 tahun 2011 tentang Badan Penyelenggara Jaminan Sosial (BPJS) yang terdiri dari BPJS kesehatan dan BPJS ketenagakerjaan. Untuk program jaminan kesehatan yang di selenggarakan oleh BPJS kesehatan, implementasinya telah dimulai sejak 1 januari 2014.

James Anderson (Natalia, Mardiyono, \& Said, 2014) memberikan pengertian atas definisi kebijakan publik "serangkaian kegiatan yang mempunyai maksud/tujuan tertentu yang diikuti dan dilaksanakan oleh seorang aktor atau sekelompok aktor yang berhubungan dengan suatu permasalahan atau suatu hal yang diperhatikan". Konsep ini menjelaksan bahwa apa yang sesungguhnya dikerjakan oleh seorang actor atau sekelompok aktor dalam hal ini pemerintah untuk suatu permasalahan. Implementasi kebijakan adalah tahap yang penting dalam kebijakan. Tahap ini menentukan apakah kebijakan yang ditempuh oleh pemerintah benar-benar baik di lapangan dan dapat berhasil sesuai dengan apa yang telah direncanakan. Implementasi juga dapat dikonseptualisasikan sebagai proses karena didalamnya terjadi beberapa rangkaian aktivitas yang berkelanjutan.

Implementasi kebijakan publik dikatakan sebagai suatu proses karena di dalamnya terdapat aktivitas, maka menurut
Sabatier and Mazmanian (Kurniawan, 2011) mengatakan bahwa implementasi kebijakan merupakan aktivitas-aktivitas yang terjadi setelah penerbitan perintah dari otoritas pemangku kebijakan publik termasuk usahausaha baik dari aspek pelaksana dan dampak substantifnya terhadap rakyat.

Dalam hal mengenai pelayanan kesehatan merupakan masalah yang sangat penting dan yang harus ditangani secara baik oleh pemerintah. Salah satu kebijakan pemerintah dalam hal penyelenggaraan jaminan kesehatan merupakan kebijakan pemerintah untuk perlindungan kesehatan agar seluruh masyarakat Indonesia mendapatkan pemeliharaan kasehatan dan perlindungan dalam memenuhi kebutuhan dasar kesehatan yang diberikan kepada setiap orang yang telah membayar iuran atau iurannya dibiayai oleh pemerintah.

Sejak program Pemerintah ini dilaksanakan masih banyak masyarkat yang belum memahami apa manfaat dari program tersebut, hal ini disebabkan karena masih kurangnya sosialisasi pemerintah terhadap masyarakat.

Pra Research yang dilakukan peneliti dimana ada beberapa penyakit tertentu tidak bisa di layani di rumah sakit, pihak Badan Penyelenggara Jaminan Sosial (BPJS) menjelaskan bahwa penyakit-penyakit tertentu hanya bisa dilayani di Puskesmas. Hal ini menjadi permasalahan buat masyarkat dimana banyak masyarakat mengharapkan pelayanan terbaik yang dapat di disiapkan oleh pemerintah.

\section{METODE}

Metode yang digunakan dalam penelitian ini adalah metode kualitatif 
deskriptif. Penelitian ini disajikan dengan menggunakan narasi yang menggambarkan bagaimana Implementasi kebijakan Jaminan Kesehatan Nasional dan hambatanhambatan apa sajakah yang ditemui pada Implementasi Undang-Undang No 24 Tahun 2014 Tentang Badan Penyelenggara Jaminan Sosial di Kabupaten Halmahera Utara. Datadata diperoleh dari Informan yang di tentukan secara purposive sampling.

Data dianalisis dengan menggunakan model interaktif terkait dengan proses yang implementasi kebijakan dengan pentahapan analisa: reduksi data, penyajian data dan penarikan kesimpulan.

\section{KAJIAN PUSTAKA Kebijakan Publik}

Negara sebagai suatu organisasi publik selain mempunyai tujuan (goals) yang harus direalisasikan, ia juga mempunyai pelbagai permasalahan yang harus diatasi, dikurangi atau dicegah. Permasalahan tersebut bisa berasal dari masyarakat itu sendiri, bisa juga berasal sebagai dampak negatif dari kebijakan yang diambil oleh pemerintah (Tachjan, 2006).

Untuk menjawab apa yang menjadi permasalahan menurut Amara Raksasataya (Wulandari, 2015) juga mengemukakan bahwa "kebijakan publik sebagai suatu taktik dan strategi yang diarahkan untuk mencapai suatu tujuan". Oleh karena itu suatu kebijaksanaan memuat 3 (tiga) elemen penting yaitu: (a) Identifikasi dari tujuan yang ingin dicapai; (b) Taktik atau strategi dari berbagai langkah untuk mencapai tujuan yang diinginkan; (c) Penyediaan berbagai input untuk memungkinkan pelaksanaan secara nyata.
Pandangan lain menjelaskan bahwa kebijakan publik merupakan pemanfaatan sumber daya untuk memecahkan masalah publik. Menurut RC. Chandler dan JC. Plano (Mariam, 2016) bahwa kebijakan publik adalah pemanfaatan yang strategis terhadap sumber daya-sumber daya yang ada untuk memecahkan masalah publik.

Setelah masalah dicarikan solusi maka para pelaksana untuk menjalankan dan menyelesaikan masalah tersebut harus melaksanakan apa yang menjadi tujuan, seperti yang telah dikemukakan oleh James Anderson (Natalia, Mardiyono, \& Said, 2014) memberikan pengertian atas definisi kebijakan publik dalam bukunya Public Policy Making, sebagai berikut "serangkaian kegiatan yang mempunyai maksud/ tujuan tertentu yang diikuti dan dilaksanakan oleh seorang aktor atau sekelompok aktor yang berhubungan dengan suatu permasalahan atau suatu hal yang diperhatikan".

Sedangkan menurut Menurut (Wulandari, 2015) mengemukakan bahwa pembuat kebijakan tidak hanya ingin melihat kebijakannya telah dilaksanakan oleh masyarakat, tetapi juga ingin mengetahui seberapa jauh kebijakan tersebut telah memberikan konsekuensi positif dan negatif bagi masyarakat. Dari sinidapat dipahami bahwa kebijakan tidak hanya untuk dibuat dan dilaksanakan dan dapat terjawab apa yang menjadi permasalahan di masyarakat.

\section{Implementasi Kebijakan}

Implementasi kebijakan merupakan pelaksanaan dari apa yang telah di buat dan harus dilaksanakan. Menurut Implementasi kebijakan publik dikatakan sebagai suatu proses karena di dalamnya terdapat aktivitas, 
maka menurut Sabatier dan Mazmanian (Kurniawan, 2011) Implementasi kebijakan adalah aktivitas-aktivitas yang terjadi setelah penerbitan perintah dari otoritas pemangku kebijakan publik termasuk usaha-usaha baik dari aspek pelaksana dan dampak substantifnya terhada prakyat.

Van Meter dan Van Horn (Lusiana, 2018) menjelaskan bahwa implementasi kebijakan, sebagai suatu tindakan yang dilakukan baik oleh individu atau pejabatpejabat atau kelompok-kelompok pemerintah atau swasta yang diarahkan untuk tercapainya tujuan yang telah digariskan dalam keputusan kebijakan. Terdapat lima variabel yang mempengaruhi kinerja implementasi kebijakan. Kelima variabel tersebut sebagai berikut: (1) Standar dan sasaran kebijakan; (2) Sumberdaya; (3) Komunikasi antar organisasi dan penguatan aktivitas; (4) Karakteristik agen pelaksana; (5) Kondisi-kondisi sosial, ekonomi, dan politik (Wisakti, 2008).

Kelima hal tersebut merupakan merupakan hal yang penting untuk di siapkan agar apa yang menjadi tujuan dari pelaksanaan kebijakan tersebut dapat terlaksana dengan baik.

Setelah dilaksanakan kebijakan tersebut proses evaluasi pun harus di buat agar apa yang menjadi tujuan dari kebijakan tersebut dapat dilihat. Seperti yang telah dikemukakan oleh (Nurharjadmo, 2008). Suatu kebijakan setelah di implementasikan perlu di evaluasi sehingga apa yang mengetahui apakah kebijakan tersebut tepat sasaran atau tidak sesuai dengan apa yang menjadi kebutuhan masayarakat. Menurut (Nurharjadmo, 2008) Evaluasi kebijakan dilakukan untuk mengetahui 4 (empat) aspek yaitu: 1) Proses pembuatan kebijakan, 2) Proses implementasi kebijakan, 3) Konsekuensi kebijakan, 4) Efektivitas dampak kebijakan.

\section{HASIL DAN PEMBAHASAN}

\section{Implementasi Kebijakan Jaminan Kesehatan Nasional}

Salah satu kajian dalam ilmu kebijakan publik adalah bagaimana suatu kebijakan dibuat dan di imlementasikan. Dalam perkembanganya suatu kebijakan yang di buat harus dimplementasikan dengan baik. Dalam proses implementasi, implementor atau pelaksana diharapkan dapat memahami dengan baik apa yang menjadi tujuan dari suatu kebijakan tersebut. Dalam menyusun sebuah kebijakan, pemerintah memerlukan pelaku dalam setiap prosesnya, baik itu pemerintah (negara) maupun masyarakat sebagai target/sasaran dari kebijakan tersebut.

Dalam praktik pelaksanaan jaminan kesehatan nasional (JKN), kondisi dilapangan menunjukkan bahwa tidak semua pelaksana kebijakan memahami dengan baik bagaimana prosedur untuk mengklaim jaminan kesehatan yang ada bagi peserta JKN. Hal ini dapat menyebabkan suatu kebijakan tidak berjalan dengan baik.

Van Meter dan Van Horn (Lusiana, 2018) juga mendefenisikan implementasi kebijakan, sebagai suatu tindakan yang dilakukan baik oleh individu atau pejabatpejabat atau kelompok-kelompok pemerintah atau swasta yang diarahkan untuk tercapainya tujuan yang telah digariskan dalam keputusan kebijakan. Salah satu hal penting yang tidak pernah lepas dari pada suatu keberhasilan suatu kebijakan yakni Implentor harus memahami dengan baik apa 
yang menjadi tujuan dari suatu kebijakan. Impelementasi kebijakan merupakan suatu hal yang penting dalam pelaksanaan kebijakan yang telah di buat, karena dimana salah satu faktor penentu dalam bagaimana mencapai hasil yang baik dari suatu kebijakan adalah implementor. Implementasi kebijakan adalah pelaksanaan keputusan kebijakan dasar baik yang bersifat dalam bentuk undang-undang, perintah atau keputusan yang di buat oleh eksekutif.

Masalah lain yang timbul dari kebijakan pemerintah ini mengenai jaminan kesehatan ini adalah masih banyak masyarakat yang belum memahami bagaimana prosedur untuk mendaftar sebagai peserta anggota BPJS. Hal ini disebabkan karena sosialisasi yang diberikan oleh pemerintah masih belum secara maksimal. Berikut ini daftar peserta yang terdaftar sampai pada bulan februari Tahun 2015.

Tabel 1.

Jumlah Penduduk yang Memiliki Jaminan Kesehatan Tahun 2015

\begin{tabular}{clccc}
\hline & & \multicolumn{3}{c}{ JUMLAH PESERTA } \\
\cline { 3 - 5 } No. & \multicolumn{1}{c}{ NAMA } & $\begin{array}{c}\text { NON } \\
\text { PBI }\end{array}$ & PBI & $\begin{array}{c}\text { JUMLAH } \\
\text { TOTAL }\end{array}$ \\
\hline 1 & Malifut & 917 & 4.078 & 4.995 \\
2 & Kao & 1.401 & 3.067 & 4.468 \\
3 & Kao Utara & 190 & 4.921 & 5.111 \\
4 & Kao Barat & 80 & 3.720 & 3.786 \\
5 & Kao Teluk & 83 & 1.726 & 1.809 \\
6 & Tobelo & 6.123 & 5.395 & 11.608 \\
7 & Tobelo Tengah & 551 & 3.777 & 4.328 \\
8 & Tobelo Utara & 428 & 4.108 & 4.536 \\
9 & Tobelo Selatan & 753 & 5.508 & 6.261 \\
10 & TobeloTimur & 88 & 4.168 & 4.256 \\
11 & Tobelo Barat & 80 & 2.502 & 2.582 \\
12 & Galela & 1.600 & 3.887 & 5.487 \\
13 & Galela Utara & 151 & 5.671 & 5.822 \\
14 & Galelaselatan & 363 & 3.475 & 3.878 \\
15 & Galela Barat & 202 & 1.986 & 2.188 \\
16 & Loloda Utara & 70 & 5.558 & 5.628 \\
17 & LolodaKepulauan & 88 & 5.208 & 5.296 \\
\hline
\end{tabular}
\begin{tabular}{cccc}
\hline JUMLAH & $\mathbf{1 3 . 2 4 4}$ & 68.755 & $\mathbf{8 1 . 9 9 9}$ \\
\hline Sumber: Data rekapitulasi jumlah peserta BPJS
\end{tabular} Kesehatan Cabang Halmahera Utara, Diolah Februari 2015)

Jika dibandingkan dengan jumlah penduduk, angka partisipasi masyarakat dalam memanfaatkan jaminan kesehatan yang menjadi icon keberpihakan pemerintah kepada masyarakat masih minim partisipasi. Jumlah penduduk tahun 2015 dapat dilihat dalam tabel berikut:

Tabel 2.

Data Penduduk Kabupaten Halmahera Utara Tahun 2015

\begin{tabular}{|c|c|c|c|c|}
\hline \multirow{2}{*}{ No } & \multirow{2}{*}{ Kecamatan } & \multicolumn{2}{|c|}{$\begin{array}{l}\text { Penduduk } \\
\end{array}$} & \multirow[b]{2}{*}{ Jumlah } \\
\hline & & Laki-Laki & Perempuan & \\
\hline 1 & Galela & 4,793 & 4,701 & 9,494 \\
\hline 2 & Tobelo & 18,043 & 17,239 & 35,282 \\
\hline 3 & $\begin{array}{l}\text { Tobelo } \\
\text { Selatan }\end{array}$ & 7,764 & 7,563 & 15,327 \\
\hline 4 & Kao & 4,742 & 4,461 & 9,203 \\
\hline 5 & Malifut & 6,028 & 5,800 & 11,828 \\
\hline 6 & $\begin{array}{l}\text { Loloda } \\
\text { Utara }\end{array}$ & 5,454 & 5,001 & 10,455 \\
\hline 7 & Tobelo Utara & 5,408 & 5,400 & 10,808 \\
\hline 8 & $\begin{array}{l}\text { Tobelo } \\
\text { Tengah }\end{array}$ & 6,815 & 6,587 & 13,402 \\
\hline 9 & TobeloTimur & 3,265 & 2,997 & 6,262 \\
\hline 10 & Tobelo Barat & 3,050 & 2,807 & 5,857 \\
\hline 11 & Galela Barat & 5,681 & 5,303 & 10,984 \\
\hline 12 & Galela Utara & 4,482 & 4,054 & 8,536 \\
\hline 13 & $\begin{array}{l}\text { Galela } \\
\text { Selatan }\end{array}$ & 4,884 & 4,711 & 9,595 \\
\hline 14 & $\begin{array}{l}\text { Loloda } \\
\text { Kepulauan }\end{array}$ & 4,115 & 3,833 & 7,948 \\
\hline 15 & Kao Utara & 6,141 & 5,692 & 11,833 \\
\hline 16 & Kao Barat & 4,923 & 4,349 & 9,272 \\
\hline 17 & Kao Teluk & 2,402 & 2,256 & 4,658 \\
\hline & Jumlah & 97,990 & 92,754 & 190,744 \\
\hline $\begin{array}{l}\text { Sun } \\
\text { Sipi } \\
\text { (Dir }\end{array}$ & $\begin{array}{l}\text { ber: Dinas } \\
\text { Kabupater } \\
\text { lah) }\end{array}$ & $\begin{array}{l}\text { Kependuc } \\
\text { Halmahe }\end{array}$ & $\begin{array}{l}\text { ukan dan } \\
\text { a Utara tah }\end{array}$ & $\begin{array}{l}\text { Catatan } \\
\text { un } 2015\end{array}$ \\
\hline $\begin{array}{l}\text { Dar } \\
\text { dije }\end{array}$ & $\begin{array}{l}\text { data sek } \\
\text { skan bahy }\end{array}$ & $\begin{array}{l}\text { under di } \\
\text { ra perbec }\end{array}$ & $\begin{array}{ll}\text { tas } & \text { maka } \\
\text { aan } & \text { yang }\end{array}$ & $\begin{array}{r}\text { dapat } \\
\text { sangat }\end{array}$ \\
\hline
\end{tabular}


signifikan dimana masih banyak penduduk yang belum mengikutsertakan dalam program jaminan kesehatan nasional.

Amara Raksasataya (Wulandari, 2015) juga mengemukakan bahwa "kebijakan publik sebagai suatu taktik dan strategi yang diarahkan untuk mencapai suatu tujuan". Oleh karena itu suatu kebijaksanaan memuat 3 elemen yaitu : (a) Identifikasi dari tujuan yang ingin dicapai; (b) Taktik atau strategi dari berbagai langkah untuk mencapai tujuan yang diinginkan; (c) Penyediaan berbagai input untuk memungkinkan pelaksanaan secara nyata.

Di dalam kebijakan publik selain memiliki tujuan, taktik maupun strategi untuk pencapaian tersebut juga perlu agar apa yang diinginkan tercapai dengan baik, maka dari itu di dalam pelaksanaan suatu kebijakan publik perlu menyiapakan berbagai macam cara termasuk membuatu suatu prosedur dalam pelayanan harus mumpuni agar mudah di mengerti sehingga masyarakat dapat memahami dengan baik apa yang menjadi tujuan dari suatu kebijakan pemerintah.

\section{Hambatan-Hambatan Pada Implementasi Kebijakan}

Implementasi kebijakan adalah tahap yang penting dalam kebijakan. Tahap ini menentukan apakah kebijakan yang dibuat oleh pemerintah benar-benar aplikabel di lapangan dan berhasil untuk menghasilkan output dan outcomes seperti yang telah direncanakan.

Adapun Van Metter dan Van Horn (Wisakti, 2008) menyebutkan ada lima variabel yang mempengaruhi kinerja implementasi kebijakan. Kelima variabel tersebut sebagai berikut: (1) Standar dan sasaran kebijakan; (2) Sumberdaya; (3) Komunikasi antar organisasi dan penguatan aktivitas; (4) Karakteristik agen pelaksana; (5) Kondisi-kondisi sosial, ekonomi, dan politik.

Dari aspek standar dan sasaran kebijakan dalam suatu kebijakan memiliki standardansasaran kebijakan yang harus di capai, tentang program mengenai jaminan kesehatan nasional (JKN).Berdasarkanhasil penelitian mengenai program pemerintah tentang jaminan kesehatan memiliki tujuan bahwa Indonesia sehat pada tahun 2019 dan semua masyarakat dapat menikmati pelayanan kesehatan dengan baik. Kebijakan merupakan tindakan pemerintah yang didesain untuk mencapai sejumlah hasil.

Dalam suatu kebijakan yang dibuat oleh pemerintah, perlu memperhitungkan apakah suatu kebijakan sesuai dengan apa yang menjadi kebutuhan oleh masyarakat. Maka dari pada itu dalam suatu proses pembuatan kebijakan perlu diperhatikan bukan saja dalam hal bagaimana mengimplementasikannya, akan tetapi perlu memperhatikan apakah dalam proses formulasi, sesuai dengan apa yang menjadi kebutuhan.

Pembuat kebijakan tidak hanya ingin melihat kebijakannya telah dilaksanakanoleh masyarakat, tetapi juga ingin mengetahui seberapa jauh kebijakan tersebut telah memberikan konsekuensi positif dan negatif bagi masyarakat (Wulandari, 2015). Dari sini dapat dipahami bahwa kebijakan tidak hanya untuk dibuat dan dilaksanakan dan dapat terjawab apa yang menjadi permasalahan di masyarakat.

Kemudian peneliti mengajukan pertanyaan mengenai dampak yang terjadi 
baik yang diharapkan atau yang tidak diharapkan (Keberhasilan/kegagalan). Maka dapat disimpulkan bahwa dampak yang diharapkan adalah agar semua masyarakat Indonesia mau bergabung dengan kebijakan pemerintah mengenai jaminan kesehatan nasional agar seluruh masyarakat dapat menikmati pelayanan kesehatan yang disediakan oleh pemerintah. Berdasarkan hasil penelitian bahwa dampak dari kebijakan yang dibuat oleh pemerintah sangat baik, karena masyarakat dapat menikmati pelayanan kesehatan yang baik yang telah disiapkan oleh pemerintah. Dampak lain yang timbul dari pelaksanaan kebijakan tersebut adalah masih ada masyarkat yang mengeluhkan akan pelayanan yang diberikan oleh pihak badan penyelenggara jaminan sosial(BPJS), hal ini dikarenakan sistem rujukannya berjenjang. Sistem rujukan yang diberikan secara berjenjang sangat baik akan tetapi harus ditunjang dengan fasilitas yang tersedia di fasilitas pelayanan tingkat pertama.

Penyediaan fasilitas dan membangun kepercayaan masyarakat merupakan suatu hal yang penting, hal ini dimaksudkan agar apa yang menjadi tujuan pemerintah dapat dicapai. Berdasarkan Peraturan Menteri Kesehatan Tujuan dari pelaksanaan Jaminan Kesehatan Nasional(Menteri Kesehatan RI, 2014) Pelaksanaan Program Jaminan Kesehatan Nasional (JKN) untuk memberikan perlindungan kesehatan dalam bentuk manfaat pemeliharaan kesehatan dalam rangka memenuhi kebutuhan dasar kesehatan yang diberikan kepada setiap orang yang telah membayar iuran atau iurannya dibayar oleh pemerintah.
Negara sebagai suatu organisasi publik selainmempunyai tujuan (goals) yang harus direalisasikan, ia juga mempunyai pelbagai permasalahan yang harus diatasi, dikurangi atau dicegah. Permasalahan tersebut bisa berasal dari masyarakat itu sendiri, bisa juga berasal sebagai dampak negatif dari kebijakan yang diambil oleh pemerintah (Tachjan, 2006). Setiap kebijakan yang dibuat oleh pemerintah memiliki tujuan yang harus dicapai, akan tetapi apa yang dibuat oleh pemerintah terkadang apa yang dibuat oleh pemerintah tidak sesuai dengan apa yang dibutuhkan masyarakat.

Sutu kebijakan yang dibuat oleh pemerintah dalam perjalananya perlu di evaluasi sehingga apa yang menjadi kelemahannya dapat di ketahui. Dalam kaitannya dengan suatu program biasanya evaluasi dilakukan dalam rangka mengukur efek suatu program dalam mencapai tujuan yang ditetapkan (Nurharjadmo, 2008). Suatu kebijakan setelah di implementasikan perlu di evaluasi sehingga apa yang mengetahui apakah kebijakan tersebut tepat sasaran atau tidak sesuai dengan apa yang menjadi kebutuhan masayarakat. Evaluasi kebijakan dilakukan untuk mengetahui 4 aspek yaitu: 1) Proses pembuatan kebijakan, 2) Proses implementasi kebijakan, 3) Konsekuensi kebijakan, 4) Efektivitas dampak kebijakan (Nurharjadmo, 2008).

Dalam memberikan pelayanan implementor harus memahami betul apa yang menjadi standar operasional prosedur yang di tetapkan oleh pihak BPJS kesehatan. Fungsi dari standar operasional prosedur (SOP) menjadi pedoman bagi setiap implementor dalam bertindak.Berdasarkan hasil penelitian mengenai standar operasional prosedur yang 
di buat oleh badan penyelenggara jaminan sosial kesehatan maka dapat disimpulkan bahwa Implementor belum memahami dengan baik apa yang menjadi standar operasional prosedur dalam pelayanan kepada masyarakat.

Standar operasional prosedur adalah hal wajib yang harus di siapkan, dalam rangka mempermudah pelayanan kepada masyarakat. Mengingat hal ini sangat penting maka implementor harus memahami dengan baik apa yang menjadi standar yang telah di buat oleh pemerintah. Untuk mencapai standar dan sasaran kebijakan kebijakan maka diperlukan standar operasional prosedur yang jelas. Sasaran kebijakan pada dasarnya adalah apa yang hendak dicapai oleh program atau kebijakan, baik yang berwujud maupun tidak, jangka pendek, menengah atau panjang. Kejelasan dan sasaran kebijakan harus dapat dilihat secara spesifik sehingga di akhir program dapat diketahui keberhasilan atau kegagalan dari kebijakan atau program yang dijalankan.

Dalam mengimplementasikan suatu kebijakan sumber daya merupakan suatu hal yang penting untuk menunjang suatu keberhasilan dari kebijakan yang di buat. Berdasarkan hasil temuan peneliti dilapangan bahwa dalam pelaksanaan jaminan kesehatan nasional sumber pendanaannya diberikan oleh pemerintah dari anggaran pendapatan belanja negara (APBN), dan anggaran yang di dapatkan cukup untuk digunakan, tetapi dalam proses pembayaran jasa kepada rumah sakit terkadang sering tidak tepat waktu. Hambatan lain yang di temui peneliti di lapangan adalah masih kurangya sumber daya manusia dan alat-alat penunjang di lapangan.
Dalam suatu kebijakan yang di buat apabila tidak di dukung dengan ke dua hal tersebut diatas maka kebijakan tersebut tidak dapat berjalan dengan baik. Sumber daya juga penting dalam implementasi kebijakan, baik sumber daya manusia (human resources) maupun sumber daya non-manusia (nonhuman resources) karena sumber-sumber tersebut menunjang keberhasilan implementasi kebijakan. Sumber daya manusia yang dimaksud adalah para pelaku kebijakan atau pelaksana kebijakan, sedangkan sumber daya non-manusia yang dapat berupa sumber daya anggaran, fasilitas dan waktu.

Pandangan yang lain mengenai kebijakan publik menurut RC. Chandler dan JC. Plano (Mariam, 2016) bahwa kebijakan publik adalah pemanfaatan yang strategis terhadap sumber daya-sumber daya yang ada untuk memecahkan masalah publik. Implementor dalam mengimplementasikan kebijakan diperlukan kemampuan untuk memanfaatkan sumber daya yang tersedia. Sehingga dalam satu kebijakan yang diimplementasikan dapat memanfaatkan sumber daya baik sumber daya manusia dan sumber daya non manusia. Pemanfaatan sumber daya manusia yang baik dimaksudkan agar dapat menunjang pelayanan yang diberikan kepada masyarakat.

Komunikasi antar organisasi merupakan suatu hal penting untuk menunjang keberhasilan dari suatu kebijakan. Komunikasi dalam hal ini merupakan bagaimana pihak-pihak yang terlibat dalam menjalankan kebijakan berkoordinasi untuk mencapai tujuan dari kebijakan tersebut. 
Dalam proses implementasi program Jaminan Kesehantan Nasional (JKN) di Kabupaten Halmahera Utara, dalam hal ini Badan Penyelenggara Jaminan Sosial Kesehatan sebagai pelaksana program, komunikasi dalam bentuk koordinasi antara mitra kerja BPJS sesuai hasil penelitian dapat disimpulkan bahwa adanya koordinasi antara badan penyelenggara jaminan sosial kesehatan dan mitra kerja lainnya, akan tetapi koordinasi yang dibuat belum berjalan secara maksimal hal ini disebabkan karena ada rujukan penyakit-penyakit tertentu yang hanya dapat di lakukan di puskemas, akan tetapi masalah lain yang timbul yaitu masih terbatas sumber daya manusia dan alat-alat penunjang, sehingga pelayanan yang seharusnya di berikan di puskesmas harus di rujuk ke rumah sakit.

Komunikasi antar organisasi, dalam implementasi suatu program perlu hubungan yang baik antar instansi yang terkait, yaitu dukungan komunikasi dan koordinasi. Untuk itu, diperlukan koordinasi dan kerjasama antar instansi bagi keberhasilan suatu program tersebut. Komunikasi dan koordinasi merupakan salah satu urat nadi dari sebuah organisasi agar program-programnya tersebut dapat direalisasikan dengan tujuan serta sasarannya.

Dari pendapat diatas maka dapat dijelaskan bahwa komunikasi dan kordinasi merupakan satu hal yang tidak dapat dipisahkan dalam mengimplementasikan suatu kebijakan, hal ini dikarenakan agar organisasi-organisasi yang menjadi mitra kerja dapat bekerja sama dengan baik sesuai dengan tujuan dari kebijakan tersebut.

Pelaksanaan sebuah program yang dibuat oleh pemerintah di pengaruhi oleh karakteristik badan pelaksana yang menjalankan kebijakan tersebut, maka hasil temuan peneliti di lapangan terkait ketiga hal tersebut adalah sebagai berikut. Dalam pelaksanaan jaminan kesehatan nasional pemerintah memberikan kepercayaan kepada badan penyelenggara jaminan kesehatan nasional dalam memberikan pelayanan kepada masyarakat, terkait dengan hal tersebut pihak badan penyelenggara jaminan sosial kesehatan (BPJS) telah berupaya memberikan response dengan baik, akan tetapi ada beberapa hal yang menjadi kendala dari mitra kerja badan penyelenggara jaminan sosial kesehatan (BPJS) yakni pihak rumah sakit dan pihak Puskesmas sebagai mitra kerja BPJS kesehatan ada hal-hal yang menjadi penghambat dalam memberikan pelayanan yakni keterbatasan akan sumber daya manusia dan alat-alat penunjang dalam memberikan pelayanan. Temuan lain yaitu mengenai kognisi yaitu pemahaman implementor terhadap kebijakan tersebut, berdasarkan hasil wawancara peneliti dengan informan maka dapat di jelaskan bahwa implementor memahami dengan baik apa yang menjadi tujuan dan tanggung jawab di setiap tugas dan pekerjaan yang telah diberikan.Mengenai preferensi nilai yang di miliki oleh badan pelaksana kebijakan berdasarkan hasil penelitian maka dapat diketahui adalah nilai yang dijadikan rujukan dalam mengimplementasikan kebijakan tersebut adalah nilai ketaatan pada peraturan perundang-undangan yang berlaku, sehingga undang-undang menjadi pedoman dalam pelaksanaan kebijakan tersebut.

Menurut Van Meter dan Van Horn dalam mengimplementasikan suatu kebijakan ada hal penting yang harus di perhatikan 
yaitu karakteristik badan pelaksana: (1) tanggapan respons atau tanggapan pelaksana terhadap kebijakan; (2) kognisi, yakni pemahaman pelaksana terhadap kebijakan; dan (3) intensitas disposisi pelaksana, yakni preferensi nilai yang dimiliki oleh pelaksana.

Kondisi eksternal pelaksana kebijakan mempengaruhi berjalannya suatu kebijakan, dimana dalam suatu organisasi pelaksana terjalin suasana kerja yang baik akan sangat efektif dalam mengimplementasikan kebijakan. Begitu pula sebaliknya, apabila di dalam suatu organisasi pelaksana tidak terbangun suatu suasana yang baik maka dalam mengimplementasikan kebijakan tersebut tidak berjalan secara maksimal. Selaian suasana kerja yang perlu di bangun perlu di perhatikan bahwa apa yang menjadi sasaran kebijakan dibuat yakni tersedianya pelayanan kesehatan yang pro terhadap masyarakat. Berdasarkan hasil penelitian kondisi sosial, ekonomi berpengaruh terhadap pencapaian tujuan dari satu kebijakan, dimana kebijakan yang di buat memiliki target/sasaran permasalahan untuk diselesaikan, akan tetapi masalah timbul dari implementasi kebijakan tersebut ialah masih ada masayarakat yang mengeluhkan akan besaran iuran yang di tetapkan, sehingga masih ada masyarakat yang belum tertarik untuk mengikuti program jaminan kesehatan yang telah disediakan oleh pemerintah. Sedangkan untuk kondisi politik dalam organisasi pelaksanan sendiri yaitu apa yang menjadi tujuan untuk menyelasikan suatu permasalahan yang terjadi di masyarakat dapat tercapai.

Salah satu hal yang tak kala penting yang dapat dijadikan faktor penghambat dalam mengimplementasikan kebijakan adalah kondisi sosial, ekonomi, dan politik. Lingkungan eksternal turut mendorong keberhasilan kebijakan publik yang telah ditetapkan. Lingkungan sosial, ekonomi dan politik yang tidak kondusif dapat menjadi biang keladi dari kegagalan kinerja implementasi kebijakan. Karena itu, upaya untuk mengimplementasikan kebijakan harus pula memperhatikan kondisi lingkungan eksternal.

Pemahaman diatas menjelaskan bahwa keberhasilan dalam mengimplementasikan kebijakan pemerintah yang dibuat adalah bagaimana lingkungan eksternal pelaksana kebijakan tertsebut mendorong penuh apa yang menjadi tujuan dari kebijakan yang telah dibuat oleh pemerintah dengan memperhatikan lingkungan eksternal dari organisasi pelaksana dan sasaran dari kebijakan tersebut.

\section{KESIMPULAN}

Dari hasil penelitian ini maka dapat di simpulkan bahwa masih banyak masyarakat yang belum mengikut sertakan diri sebagai peserta jaminan kesehatan nasional. Hal ini disebabkan karena masih kurangnya sosialisasi pemerintah terhadap masayakat. Dalam kebijakan mengimplementasikan kebijakan ini ada beberapa hal yang dapat di menjadi hambatan yaitu: masih kurangnya fasilitas penunjang dan masih kurangnya sumber daya manusia yang tersedia untuk memberikan pelayanan, hal lain yang menjadi penghambat dalam pelaksanaan kebijakan ini adalah implementor belum memahami dengan baik, Standar operasional prosedur dalam memberikan pelayanan, dan terkadang komunikasi dan koordinasi yang di bangun antara pihak BPJS dan mitra kerjanya belum 
berjalan dengan baik. Dari hasil penelitian ini maka disarakan agar pemerintah lebih giat lagi dalam melakukan sosialisasi kepada masyarakat dan Implementor yang menjalakan kebijakan ini sehingga baik itu itu pemerintah dan masyarakat memahami dengan baik apa yang menjadi tujuan dari kebijakan ini. Hal lain yang tak kala pentingnya adalah pemerintah harus mempersiapkan fasilitas penunjang dan sumber daya manusia agar dalam memberikan pelayanan kepada masyarakat dapat terlaksana dengan baik

\section{DAFTAR PUSTAKA}

Implementasi Program Indonesia Pintar (PIP) Di Desa Sukomulyo Kecamatan Sepaku Kabupaten Penajam Paser Utara (Studi Kasus di SDN 011 dan SDN 013). (2018). eJournal Administrasi Negara (6) , 6991-7005.

Iva, M. I. (2014). Implementasi Kebijakan Jaminan Kesehatan Nasional Melalui Badan Penyelenggara Jaminan Sosial (BPJS) Kesehatan Di Kota Makassar. (1) , 149.

Kurniawan, B. D. (2011). Implementasi Kebijakan Sertifikasi Guru dalam Rangka Meningkatkan Profesionalitas Guru di Kota Yogyakarta). Jurnal Studi Pemerintahan, Vol.2 (No.2) , 278-299.

Lusiana, L. (2018). Implementasi Program Indonesia Pintar (PIP) Di Desa Sukomulyo Kecamatan Sepaku Kabupaten Penajam Paser Utara (Studi Kasus di SDN 011 dan SDN 013). eJournal Administrasi Negara (6) , 6991-7005.
Mariam. (2016). Implementasi Kebijakan Jaminan Kesehatan Nasional (JKN) Pada Dinas Kesehatan Kabupaten Sigi. Jurnal Elektronik, Program Pascasarjana Universitas Tadulako, Vol.3 , 37-46.

Natalia, B. M., Mardiyono, \& Said, A. (2014). Implementasi Program Zona Air Minum Prima (ZAMP) Untuk Memenuhi Kebutuhan Air Minum Masyarakat. Jurnal Administrasi Publik, 2, , 11-15.

Nurharjadmo, W. (2008). Evaluation Implementation Dual System Education Program in Senior Technical High School. Spirit Publik, 4 (2) , 215-228.

Tachjan, H. (2006). Implementasi Kebijakan Publik (D. Mariana \& C. Paskarina, Eds.) (Cetakan 1)., . Bandung: AIPI Bandung.

Wisakti, D. (2008). Implementasi Kebijakan Alokasi Dana Desa di Wilayah Kecamatan Geyer Kabupaten Grobogan. Semarang: MAP - Universitas Diponegoro .

Wulandari, F. (2015). Analisis Kebijakan Pemerintah Dalam Penataan Minimarket Di Kota Palopo. Makassar: Universitas Hasanuddin . 